\title{
Salt incorporated diets for enhancing growth performance and survival in gilthead sea bream Sparus aurata L. juveniles reared in low saline brackish water
}

\author{
SAMUEL APPELBAUM and ANTONYSILUVAI JESUAROCKIARAJ \\ The Bengis Centre for Desert Aquaculture, The Albert Katz Department of Dryland Biotechnologies, The Jacob Blaustein \\ Institute for Desert Research, Ben-Gurion University of the Negev, Sde Boker Campus 84990, Israel. \\ E-mail: sappl@bgu.ac.il
}

\begin{abstract}
SUMMARY: Following previous observations, this study was undertaken to determine the level of salt required in the diet of gilthead sea bream (Sparus aurata L.) juveniles in order to enhance growth performances and survival when rearing in inland brackish water with a salinity of $2.9 \%$ TDS (Total Dissolved Salts). The juveniles were reared for 10 weeks in twelve rearing tanks, each stocked with 65 fish. Four different test diets were prepared: a control diet without added salt, and three diets with $12 \%, 14 \%$ and $16 \%$ added salt. Fish were fed by hand ad libitum three times daily. All diets were accepted equally well. The highest growth rate $(\mathrm{p}<0.05)$ was achieved in fish fed the $12 \%$ diet followed by the $14 \%$ diet, the control diet, and finally the $16 \%$ diet. The $12 \%$ diet produced the best specific growth rate, feed conversion ratio and protein efficiency ratio. The highest survival was achieved in fish fed the $12 \%$ diet (88\%) and the lowest in fish fed the 16\% diet (80\%) and the control diet (80\%). This study demonstrates that growth performance and survival in gilthead sea bream reared in water of low salinity can be significantly improved by adding $12 \%$ salt to their diet.
\end{abstract}

Keywords: gilthead sea bream, salt-added diet, growth and survival, low salinity, brackish water, geothermal water, arid land aquaculture.

RESUMEN: DIETAS CON SAL INCORPORADA PARA MEJORAR EL RENDIMIENTO EN EL CRECIMIENTO Y SUPERVIVENCIA DE JUVENILES DE DORADA SPARUS AURATA L. CRIADOS EN AGUAS SALOBRES DE BAJA SALINIDAD. - A raíz de las observaciones anteriores, este estudio se realizó para determinar el nivel de sal requerido en la dieta de la dorada (Sparus aurata L.) con el propósito de incrementar el crecimiento y la supervivencia en aguas salobres con salinidad de $2.9 \%$ TDS. Los juveniles $(X=0.58 \mathrm{~g})$ fueron criados durante 10 semanas en doce tanques con 65 organismos en cada uno. Cuatro dietas fueron probadas: control sin adición de sal y adicionadas con el 12, 14 y $16 \%$ de sal. Los peces fueron alimentados ad libitum manualmente tres veces al día. Todas las dietas fueron bien aceptadas, sin embargo la mayor tasa de crecimiento se obtuvo con la dieta que adicionaba el $12 \%$, seguida por la del $14 \%$, la dieta control y la de $16 \%$ de sal agregada $(\mathrm{p}<0.05)$. La mayor tasa de crecimiento específico, conversión alimenticia y relación de eficiencia proteica se observó con la dieta del 12\%. La mayor supervivencia (88\%) se encontró con la dieta del $12 \%$ y la menor con $16 \%$ y en el grupo control $(80 \%)$. Este estudio demuestra que el crecimiento en la dorada criada en aguas de baja salinidad puede mejorarse significativamente mediante la adición del $12 \%$ de sal a su dieta.

Palabras clave: dorada, sal dieta, crecimiento, supervivencia, baja salinidad, agua salobre, agua geotérmica, acuicultura de las tierras áridas.

\section{INTRODUCTION}

Gilthead sea bream is a euryhaline teleost capable of living in environments with salinities ranging from $2 \%$ o to $60 \%$. Its natural habitat stretches from the Mediterranean and Black Sea to the eastern At- lantic Ocean from Senegal to the United Kingdom. It is commonly found in shallow lagoons along the coast, but migrates into deeper water to spawn after late autumn. Fish in low-saline water show a passive outward flux of ions such as $\mathrm{Na}^{+}$and $\mathrm{Cl}^{-}$to the water via the gills, faeces and renal system, which 
must be compensated by the active uptake of ions from the water and/or from the diet. Gills, the major osmoregulatory organ in fish, undergo large morphological changes at low water salinities. Euryhaline fish in different environmental salinities induce activation of their ion transport mechanism, usually accompanied by changes in oxygen consumption, causing variations in the energy demands for osmoregulation.

Since minerals absorbed from the water do not always meet the total metabolic requirements in fish, their supplementation through the diet promotes growth (Hepher, 1988). Fish diet is therefore an important source of salts not only to satisfy the needs for growth, but also for osmoregulation. Providing a sufficient amount of salt through feeds can spare energy that is used for osmoregulation, thereby reducing stress and allowing more energy for growth. Dietary salt has been found to be beneficial for growth in rainbow trout (MacLeod, 1978), common carp and mrigal (Nandeesha et al., 2000), Asian sea bass (Harpaz et al., 2005), European sea bass (Eroldogan, 2003; Eroldogan et al., 2005) and gilthead sea bream (Appelbaum et al., 2008a, b; Appelbaum and Arockiaraj, 2008b, 2009). Salman and Eddy (1988) and Smith et al. (1995) found that feeding rainbow trout with a $12 \%$ salt-added diet promoted better growth, better survival and a better feed conversion ratio, but the inclusion of over $12 \%$ salt resulted in a deterioration in all growth performances. Yakupitiage (1993) reported that the use of salt as a supplement in fish feed is a normal practice in China and India. Veerina et al. (1993) reported that about $44 \%$ of the freshwater fish farmers in the southern state of India use salt as an additive to fish diets.

Recent studies by Appelbaum et al. (2008a, b) showed that gilthead sea bream juveniles reared in brackish water (3\% TDS) and fed a diet supplemented with $1.5 \%$ salt grew significantly $(\mathrm{p}<0.05)$ better than those fed the control diet (no added salt). Appelbaum and Arockiaraj (2008a) reported that rearing the juveniles of gilthead sea bream in low salinity brackish water (2.9-3.6\% TDS) significantly improved their growth and survival rates when they were fed $6 \%$ salt-added diets. A further study (Appelbaum and Arockiaraj, 2008b) using diets supplemented with higher levels of salt $(8 \%, 10 \%$ and $12 \%)$ showed that gilthead sea bream juveniles reared in brackish water of $2.9 \%$ (TDS) salinity grew better and had the highest survival rate when fed a diet consisting of $12 \%$ added salt. Following these previ- ous observations, the present study was undertaken to determine the required levels of salt incorporated in the diet for enhancing growth performances and survival of gilthead sea bream (Sparus aurata L.) juveniles reared in low-saline inland brackish water.

\section{MATERIALS AND METHODS}

\section{Experimental system}

Twelve rectangular plastic rearing tanks of 60-L capacity were used for the study. Each tank was filled with water of $2.9 \%$ (TDS) salinity originating from a deep brackish water well in the southern region of the Israeli Negev desert. The rearing tanks were grouped into 4 separate systems. Each system consisted of three rearing tanks connected to a 100-L water-cleaning unit filled with volcanic gravel and strongly aerated water acting as a mechanical and biological filter. Water from the cleaning unit entered each rearing tank at the rate of $3 \mathrm{~L}$ per minute. Thirty percent of the rearing water was renewed daily in each system. Continuous aeration was provided by a blower with diffused air stones keeping oxygen levels above $4 \mathrm{ppm}$. The water temperature was maintained at $28 \pm 1^{\circ} \mathrm{C}$ using thermostatically controlled electric heaters. Ammonia and nitrite were kept at recommended levels for gilthead sea bream.

\section{Experimental fish}

Gilthead sea bream juveniles with an average initial wet weight of $0.58 \mathrm{~g}$ were used for the 10week feeding trial. Each rearing tank was randomly stocked with 65 juveniles.

\section{Experimental diets}

Four different test diets were prepared by grinding a commercial sea bream feed (protein $45 \%$, lipid 14\%, fibre 2.4\% and ash 9.5\%; "Zemach" Feed Mills, Israel), into which 5\% commercial krill meal and $5 \%$ baker's yeast were added. Before re-pelleting, salt was added to the ingredients as follows: Diet 1 , without salt, served as the control diet; Diet 2, $12 \%$ salt added; Diet 3, 14\% salt added; and Diet 4, 16\% salt added (Table 1). The salt incorporated into the diets was obtained by evaporating brackish geothermal water from the same source as the rearing water in the present experiment. After re-pelleting, the 
TABle 1. - Diet compositions (\% dry weight basis).

\begin{tabular}{lcccc}
\hline Ingredients (\%) & Diet 1 & Diet 2 & Diet 3 & Diet 4 \\
\hline Commercial sea bream feed* & 90 & 78 & 76 & 74 \\
Krill meal & 5 & 5 & 5 & 5 \\
Baker's yeast & 5 & 5 & 5 & 5 \\
Salt added & 0 & 12 & 14 & 16
\end{tabular}

* Protein $45 \%$, lipid $14 \%$, fibre $2.4 \%$, ash $9.5 \%$, calcium $2.4 \%$, phosphorous $1 \%$, copper $5 \mathrm{mg} / \mathrm{kg}$, selenium $0.3 \mathrm{mg} / \mathrm{kg}$, lysine $2.7 \%$, methionine $1 \%$, vitamin A $1200 \mathrm{IU}$, vitamin C $150 \mathrm{mg} / \mathrm{kg}$, vitamin D3 $1750 \mathrm{IU}$ and vitamin E $150 \mathrm{mg} / \mathrm{kg}$.

diets were oven-dried at $60^{\circ} \mathrm{C}$ for 6 hours and stored in an airtight container. Fish in all tanks were fed by hand ad libitum three times daily. Fish in system 1 were fed the control diet, fish in system 2 were fed the $12 \%$ salt-added diet, fish in system 3 were fed the $14 \%$ salt-added diet and fish in system 4 were fed the $16 \%$ salt-added diet.

\section{Observations}

Growth, survival and feeding rate were monitored and calculated as follows: survival $(\%)=[$ (no. of fish stocked - no. of mortalities)/ no. of fish stocked] x 100; weight gain $(\mathrm{g})=$ final mean weight - initial mean weight; weight gain $(\%)=[($ final mean weight - initial mean weight)/ initial mean weight] x 100; specific growth rate $\left(\mathrm{SGR} ; \% \mathrm{~d}^{-1}\right)=[($ In final mean weight - In initial mean weight)/ duration of the experiment] $\times 100$; feed conversion ratio $(\mathrm{FCR})=$ amount of feed provided $(\mathrm{g}) /$ weight gain $(\mathrm{g})$; and protein efficiency ratio $(\mathrm{PER})=$ weight gain $(\mathrm{g}) /$ protein intake.

\section{Statistical analyses}

The growth data were analysed using one-way ANOVA and Tukey's multiple range test (Zar, 1984).

\section{RESULTS}

Fish growth performance and survival are presented in Table 2 and Figures 1 and 2. All experimental diets were accepted by the fish equally well, the highest growth rate $(\mathrm{p}<0.05)$, however, being achieved in the fish groups fed the $12 \%$ salt-added diet, followed by those fed the $14 \%$ salt-added diet,

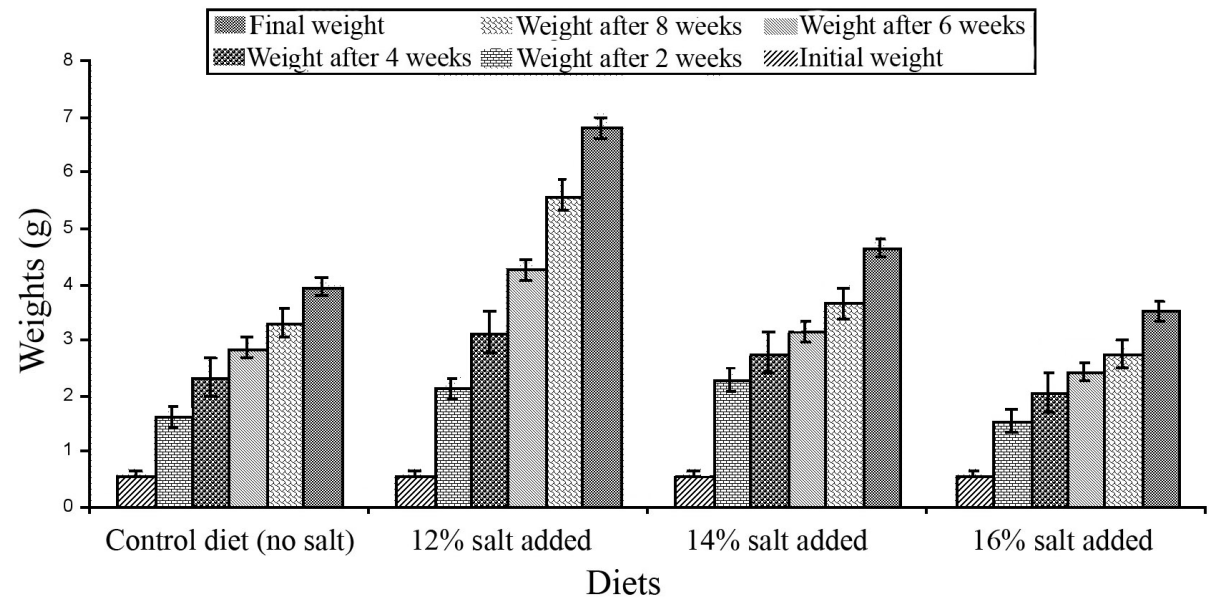

FIG. 1. - Weight gain (g) of gilthead sea bream (Sparus aurata L.) juveniles reared and fed different salt-added diets for 10 weeks. Data shown are means and standard deviations.

TABLE 2. - Growth performance of gilthead sea bream ( . aurata L.) juveniles fed different salt-added diets for 10 weeks (values given are the mean of three replicates \pm standard deviation)

\begin{tabular}{lcccc}
\hline Growth performances & Diet 1 & Diet 2 & Diet 3 & Diet 4 \\
\hline Initial weight (g) & $0.58 \pm 0.08$ & $0.58 \pm 0.08$ & $0.58 \pm 0.08$ & $0.58 \pm 0.08$ \\
Final weight (g) & $3.94^{\mathrm{a}} \pm 0.17$ & $6.81^{\mathrm{b}} \pm 0.29$ & $4.66^{\mathrm{c}} \pm 0.25$ & $3.52^{\mathrm{a}} \pm 0.26$ \\
Weight gain (g) & $3.36^{\mathrm{a}} \pm 0.58$ & $6.23^{\mathrm{b}} \pm 0.67$ & $4.08^{\mathrm{c}} \pm 0.34$ & $2.94^{\mathrm{a}} \pm 0.41$ \\
Weight gain $(\%)$ & $579 .^{\mathrm{a}} \pm 26.5$ & $1074 .^{\mathrm{b}} \pm 48.3$ & $703.4^{\mathrm{c}} \pm 37.8$ & $506.8^{\mathrm{a}} \pm 36.1$ \\
Specific growth rate $\left(\% \mathrm{~d}^{-1}\right)$ & $1.18^{\mathrm{a}} \pm 0.14$ & $1.96^{\mathrm{b}} \pm 0.23$ & $1.42^{\mathrm{c}} \pm 0.33$ & $1.05^{\mathrm{a}} \pm 0.18$ \\
Feed conversion ratio & $2.13^{\mathrm{a}} \pm 0.46$ & $1.04^{\mathrm{b}} \pm 0.68$ & $1.63^{\mathrm{c}} \pm 0.41$ & $2.44^{\mathrm{a}} \pm 0.52$ \\
Protein efficiency ratio & $1.04^{\mathrm{a}} \pm 0.18$ & $2.12^{\mathrm{b}} \pm 0.37$ & $1.36^{\mathrm{c}} \pm 0.25$ & $0.91^{\mathrm{a}} \pm 0.09$
\end{tabular}

$\mathrm{a}, \mathrm{b}$ and $\mathrm{c}$ denote significant differences at $\mathrm{p}<0.05$ level by one-way ANOVA and Tukey's multiple range test 


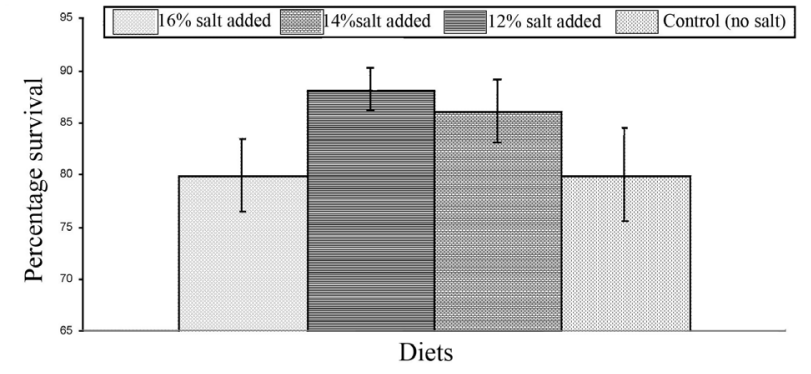

FIG. 2. - Survival (\%) of gilthead sea bream (Sparus aurata L.) juveniles reared and fed different salt-added diets for 10 weeks. Data shown are means and standard deviations.

the control diet, and finally the $16 \%$ salt-added diet, which produced the lowest growth rate. Significantly $(\mathrm{p}<0.05)$, the highest specific growth rate (SGR), feed conversion ratio (FCR) and protein efficiency ratio (PER) were also observed in the groups fed the $12 \%$ salt-added diet (Table 2 and Fig. 1). The highest survival (88\%) was achieved in fish groups fed the $12 \%$ salt-added diet and the lowest (80\%) in fish groups fed the $16 \%$ salt-added diet and the control diet (Fig. 2).

\section{DISCUSSION}

The results of the present study demonstrate that the growth of gilthead sea bream juveniles cultured in inland low-salinity brackish geothermal water can be significantly improved by incorporating $12 \%$ salt into the fish diet. Recent publications on euryhaline fish have indicated that growth and feed conversion ratio are improved by feeding diets with added salt (sodium chloride; $\mathrm{NaCl}$ ) (Nandeesha et al., 2000; Harpaz et al., 2005; Eroldogan et al., 2005). Salman and Eddy (1988) and Pelletier and Besner (1992) reported that the inclusion of more than $12 \%$ salt in salmon diets has no positive but rather negative effects on growth and feed conversion ratio. In this study, incorporating $12 \%$ salt (obtained from evaporating brackish geothermal water) into the diet significantly improved fish growth performance, with no visible detrimental effect. However, the $14 \%$ or $16 \%$ salt-added diets lowered the growth and survival rates compared with the $12 \%$ salt-added diet and the control diet (no salt added).

Many studies (Schmidt-Nielsen, 1997; SangiaoAlvarellos et al., 2003; Laiz-Carrion et al., 2005) have indicated that fish development, growth and survival are influenced by various physiological factors, one of which is water salinity. Various develop- mental stages during fish embryogenesis depend on water salinity. Salinity plays a key role in the regulation of growth, growth rate, metabolic rate, feed intake and feed conversion. In summary, the present observations indicate that for rearing gilthead sea bream juveniles in brackish water of $2.9 \%$ salinity, supplementing the fish diet with $12 \%$ salt is recommended in order to achieve a better growth performance, feed conversion ratio and survival.

\section{CONCLUSION}

This study demonstrates that when gilthead sea bream juveniles are reared in low saline brackish water, fish growth performance, feed conversion ratio and survival can be significantly enhanced by feeding a salt added diet. A $12 \%$ salt supplement was found to be the best of the tested diets for sea bream juveniles reared in brackish water with a salinity of $2.9 \%$ (TDS). This study shows that when a salt-supplemented diet is used, inland brackish water of low salinity provides a promising realistic opportunity for farming gilthead sea bream which is traditionally farmed in sea water.

\section{ACKNOWLEDGEMENTS}

The Bengis Centre for Desert Aquaculture, Albert Katz International School for Desert Studies, Blaustein Centre for Scientific Cooperation, BenGurion University of the Negev, Israel is gratefully thanked for providing the postdoctoral fellowship grant to the second author. Mr. David Benzion and Mr. Alan Wass are thanked for their technical help.

\section{REFERENCES}

Appelbaum, S and A.J. Arockiaraj. - 2008a. Israeli researchers test viability of using brackish inland waters for rearing gilthead sea bream. Hatchery Inter., 9(4): 22-23.

Appelbaum, S and A.J. Arockiaraj. - 2008b. Brackish water sea bream success. Fish Farmer Inter., 35(8): 35.

Appelbaum, S and A.J. Arockiaraj. - 2009. Cultivation of gilthead sea bream (Sparus aurata L.) in low salinity inland brackish geothermal water. AACL Bioflux, 2 (2): 197-203.

Appelbaum, S., A.J. Arockiaraj and C. Imanraj. - 2008a. Promoting the culture of gilthead sea bream (Sparus auratus L.) in low saline inland water: A novel way to farm saltwater fish in freshwater. Fish for the People, 6(1): 40-44.

Appelbaum, S., A.J. Arockiaraj and C. Imanraj. - 2008b Cultivation of gilthead sea bream (Sparus auratus L.) in low saline inland water of southern part of Israel desert. Aquaculture Asia, 13 (4): 33-36 
Eroldogan, O.T. - 2003. Acclimation of European sea bass (Dicentrarchus labrax) to freshwater and determination of its optimal feeding rates in freshwater. Ph.D. thesis, Univ. Cukurova, Adana, Turkey.

Eroldogan, O.T., M. Kumlu, M. Kir and G.A. Kiris. - 2005. Enhancement of growth and feed utilization of the European sea bass (Dicentrarchus labrax) fed supplementary dietary salt in freshwater. Aquaculture Res., 36: 361-369.

Harpaz, S., T.Y. Hakim, T. Slosman and O.T. Eroldogan. - 2005. Effects of adding salt to the diet of Asian sea bass Lates calcarifer reared in fresh or salt water re-circulating tanks, on growth and brush border enzyme activity. Aquaculture, 248: 315-324.

Hepher, B. - 1988. Nutrition of pond fishes. Cambridge University Press, New York.

Laiz-Carrión, R., P.M. Guerreiro, J. Fuentes, A.V.M. Canario, M.P. Martín del Rio and J.M. Mancera. - 2005. Branchial osmoregulatory response to salinity in the gilthead sea bream, Sparus aurata. J. Exp. Zool., 303: 563-576.

MacLeod, M.S. - 1978. Relationship between dietary sodium chloride, food intake and food conversion in the rainbow trout. $J$ Fish Biol., 13: 73-79.

Nandeesha, M.C., B. Gangadhar, P. Keshavanath and T.J. Varghese. - 2000. Effect of dietary sodium chloride supplementation on growth, biochemical composition and digestive enzyme activity of young Cyprinus carpio (Linn.) and Cirrhinus mrigala (Ham.). J. Aqua. Trop., 15: 135-44.

Pelletier, D and M. Besner. - 1992. The effects of salty diets and gradual transfer to sea water on osmotic adaptation, gill $\mathrm{Na}^{+}$ $\mathrm{K}^{+}$-ATPase activation, and survival of brood charr (Salvelinus fontinalis Mitchill). J. Fish Biol., 41: 791-803.

Salman, N.A and F.B. Eddy. - 1988. Effects of dietary sodium chloride, on growth, food intake and conversion efficiency in rainbow trout (Salmo gairdneri Richardson). Aquaculture, 70: 131-144.

Sangiao-Alvarellos, S., R. Laiz-Carrión, J.M. Guzmán, M.P. Martín del Río, J.M. Míguez, J.M. Mancera and J.L. Soengas. - 2003. Acclimation of Sparus aurata to various salinities alters energy metabolism of osmoregulatory and nonosmoregulatory organs. Am. J. Physiol., 285: R897-R907.

Schmidt-Nielsen, K. - 1997. Animal Physiology: Adaption and Environment, 5th Ed. Cambridge, UK: Cambridge University Press.

Smith, N.F., F.B. Eddy and C. Talbot. - 1995. Effect of dietary salt load on trans-epithelial $\mathrm{Na}^{+}$exchange in freshwater rainbow trout (Oncorhychcus mykiss). J. Exp. Biol., 198: 2359-2364.

Veerina, S.S., M.C. Nandeesha, K.S. Rao and S. De Silva. - 1993. Status and technology of Indian major carp farming in Andhra Pradesh. In: India Asian Fisheries Society, pp: 1-30. Indian Branch, Mangalore.

Yakupitiage, A. - 1993. On-farm feed preparation and feeding strategies for carps and tilapia. In: Farm-made Aquafeeds, Proc. FAO/AADCP Regional Expert Consultation on Farm-made Aquafeeds. FAO/RAPA/AADCP, Bangkok, Thailand.

Zar, J.H. - 1984. Biostatistical Analysis, II Edition, Prentice - Hall International Incorporation, Englewood Cliffs, New Jersey.

Received November 15, 2008. Accepted August 12, 2009.

Published online October 5, 2009. 